\title{
Fatalistic Traits in Finnish Proverbs
}

\author{
By MATTI KUUSI
}

I. In his main work Oskar Loorits characterizes Fenno-Ugrian Weltanschauung in the following way: "Sie hat durch die Seelenwanderung ohne eine präzisierte Reinkarnation, durch den Schamanismus ohne ein berufsmässiges Priestertum, durch den Manismus ohne eine Vergöttlichung der Ahnen und durch den Fatalismus ohne eine Vorherbestimmung von höherer Seite (d.h. durch den Determinismus ohne irgendeine Prädestination) ihre Originalfärbung in der Jahrtausende währenden Waldkultur herauskristallisiert."1

The verb luoda, which in modern Finnish has the basic meaning 'to create' with a strong Christian colouring, was obviously used earlier to express fatalistic ideas. Its primary meaning appears, for instance, in a laconic proverb from Perniö (in south-western Finland): Tam lua, literally "The oak creates", which is given the following explanation: "It is the weather in January [tammikuu, month of oak] that in some way predetermines what the spring and the summer will be like."

Special attention should be given to the use of the perfect passive participle luotu (modern Finnish: 'created') which in Schroderus' Lexicon LatinoScondicum (1637) is interpreted as: "Fatum, ödhe (i.e. destiny, fate), Gottes Schickung".

I quote some typical examples of proverbs in which the reference is to marital predestination:

Fokaatten täytty luatus otta, Everyone has to take his luotu.

Ei luotu poika portist palaa, mut luomaton menee viel sänkystäkin, The boy who is luotu (for a girl) does not return from the gate, but the one who is not luotu for her returns even from the bed.

1 O. Loorits, Grundzüge des estnischen Volksglaubens, Uppsala I949-57, III p. 249. 
Luotu löytyy loukosta, aijottu tulee vaikka pystöaijan takaa, or vaik yli $y$ hdeksä virra, You find (that which is) luotu (even) in the nook, the premeditated even comes through the fence (or, across nine rivers).

Luatu luakses vettä, Luotu draws (attracts) to itself.

Mihes luadustas mene, How could you escape your luotu?

Luotuunsa, suotuunsa, ei kauan katseltuunsa eikä mielen tehtyynsä, You belong to the one who is luotu for you, granted to you, not to the one whom you have long been looking for and desiring.

Luoja sen luodun tuo, vaan toinen sen toivotun vie, God brings the luotu, another (man or woman) carries away what you wish for.

The last proverb, with a Christian Creator, Luoja, is an exception to the general usage of the passive without an agent. In Lappish the word luondo has a corresponding range of meanings, e.g. Kalle mon ådtjob tab neitab jus le luondo, "I shall certainly get that girl, if she is allotted to me".1

Proverbs like the above have obviously been quoted in support of the old patriarchal marriage system. "Rarely does it happen that a girl or a young man oppose their parents' will, and that she elopes with a man or allows herself to be abducted. The girl subordinates herself and prepares herself in advance to say: $K u$ kelle on luotu mänemöä, "one is luotu to marry someone", or: koha se nï ol sallittu, "if it is ordained by Fate", or: koha se on suotuhie, luotuhie eikä mieltiettohie, "if you only end up with one who is granted, luotu (for me), and not with my beloved".2

The paratactic rhyme figure suotu-luotu occurs also in ancient poems of wooing as a cliché employed by the girl to refuse unwanted suitors. Larin Paraske, for example, who knew 32,000 verses in Kalevala metre, sang in her variant of "Suitor from the Sea" the following refusal formula:

Ei oo suotu eikä luotu,

eik o eukko toivotantu

saunan maass ei maatessaase

olkiloill ei ollessaase

pehuloill levätessääse. ${ }^{3}$

"It has not been granted, nor luotu (that I marry you), nor has my mother

1 E. Lindahl-J. Öhrling, Lexicon Lapponicum (1780) p. 222.

${ }_{2}^{2}$ Iris Kähäri, in: Räisälän historia, 2nd ed. Turku I952, p. 573.

3 Suomen kansan vanhat runot $\mathrm{V}_{3} 107$. 
wished (me for you) when she lay (in childbed) in the sauna on straw and chaff".

In some cases the difference between suotu, 'granted' and luotu is emphasized. If the wife is older than her husband it may be said: On suatu mutte o luatu, "it has been granted but not luotu". Likewise: Vaikk moni ols sul suottu, muttei ne kaik ol su vartte luottu, "Though many a one may have been granted to you, they are not all luotu for you."

The reference to the wish of the mother in childbed should probably be taken as poetic licence and hardly as an attempt to explain man's inborn destiny. Indeed, in ancient folk lyrics man's destiny is often associated with his time of birth.

Passivum fatale occurs in some ten Finnish proverbs which use a formula with luotu. Here are some examples:

Luotu on köyhä kulkemahan, vaivainen vaeltamahan, The poor man is luotu to walk around, the miserable one to wander.

Mies on luotu miekka vyölle, nainen värttinä kätehen, A man has been luotu to carry a sword in his belt, a woman to have a distaff in her hand.

Lintu on luotu lentämähän, huolellinen laulamahan, The bird is luotu to fly, the sorrowful to sing.

Thus certain behaviour is characterized as a natural necessity that cannot be evaded. There are also luodut päivät, a predestined number of days (of life): Näkeminen luodut päivät, jos nälän nähtäköön; tekeminen luodut lapset, jos tiellä tehtäköön, "You have to see your luotu days, even if it be in hunger, you have to bear your luotu children, even if it be on the road." The same fatalistic formula, based on the Finnish fourth infinitive, is found e.g. in the proverb: Pitäminen päätynyttä, jystäminen jäätynyttä, saatua syliäminen, "You have to keep that which has reached you, you have to gnaw that which has frozen, you have to embrace the one you have received."

Luotu, fatum, is not only an expression of erotic fatalism. "He that's born to be hang'd shall never be drowned" is in Finnish: foka hirtettäväks on luatu, ei se vetteen kuale. When a man ventures on to unsafe ice, he says: Ei hullummin käy kun luotu on, "It will not go worse than what is luotu (for me)". The opposite of luotu is luomaton, 'uncreated', 'not predestined'. Ei luomaton surma tapa, "A mortal danger that is luomaton does not kill", for "every man dies such a death as has been decreed for him on the 
luoma-day". The time and manner of death are predestined and cannot be altered.

2. Learned abstractions like fatalism, or destiny can only with difficulty be applied to the metaphorical thoughts of the Finnish proverbs. The word kohtalo, which corresponds to 'destiny' in the modern written language, is rare in ancient folklore and has primitive shades of meaning. In a dirge in Kanteletar (II 305) the singer says: When I die in the swampy woods the ravens get kohtaloa and the crows warm blood from my corpse. Kohtalo has here retained its old meaning of "piece of meat", "the allotted share of the common booty". 1

The only proverb that mentions kohtalo runs: Osallaan mies elää, koira toisen kohtalolla, "A man lives off his [own] share, a dog lives off another's kohtalo". Here the synonyms osa and kohtalo have a double sense: in the case of the dog the reference is to the piece of meat, but man's kohtalo is 'portion, lot, portio, sors' as Kristfrid Ganander translates the word kohtalo in his dictionary as early as the 1780 's. The idea of this proverb is central in Finnish proverbial ideology: one should be content with one's lot and not covet the lot of others. This proverb occurs for the first time in Lönnrot (I842), but its twenty variant forms come from all parts of the country and the Kalevala metre proves that it is of considerable antiquity.

The concepts osa, 'lot, share', onni, lykky, 'fortune, luck', appear in Finnish proverbs sharing similar features with the old poems. In folk songs too there are references to a concrete, personified osa or onni which accompanies man, can be divided, bought, exchanged, thrown away, which sleeps or is wakeful, and receives such parallel names as haltija (ruler, owner), synty (genius) and jumala (god). I quote some relevant proverbs.

Onni miehen tyyrmanni, Fortune is man's pilot, or Onni se miestä tyyrää, It is fortune that steers man.

Osa orjana pitävi, lykky toisen lyötävänä, One's lot makes him a slave, fortune causes him to be beaten by another, or Onni orjana pitävi, onni orjan käskijänä, It is fortune that makes one a slave, and the other the slave's master.

Osastaan ja onnestaan ihminen ei pääse yli, ei ympäri, A man can neither skip over nor dodge around his lot and his fortune.

${ }^{1}$ Cf. V. Ruoppila, “'Kohtalo' ja 'osa””, Virittäjä 37/1933 pp. 361 ff. 
Ei saa onnea ostamalla eikä lykkyä vaihtamalla, One does not get [good] fortune through purchase or exchange.

Ei ole osa ostettava eikä ikä jatkettava, One's lot cannot be bought, nor one's time extended.

Ei oo onnee, ei oo ossoo - kuka minunnii onnellain elänee, I have neither luck nor portion - who could it be that lives off my luck?

Mies makaa, onni valvoo, Man sleeps, fortune is awake.

Onnessa se on ihmisen elämä, It is on luck that human life depends.

Ei sua osua etsie, gu ei osa itsie etsinne, You should not seek your fortune if it does not itself seek you.

Uno Harva, V. J. Mansikka, Oskar Loorits, Martti Haavio, and Ivar Paulson have analyzed the concept of osa and onni, though without considering the proverbial tradition. They have produced Scandinavian and classical as well as Fenno-Ugrian and East Slavonic parallels. What I find especially interesting in this context is the fact that proverbs concerning lot and luck in the earlier material are common all over Finland, while in the 2oth century they are found predominantly in the eastern parts of the country, to a great extent only in Karelia. Even in the East new chords are now struck, e.g. Ei onni hyväinenkään syötä miestä syrjälleen, istuvalleen ei elätä, 'Not even good luck feeds a man who only lies and sits.' This proverb was found in four parishes on the Karelian Isthmus and can be regarded as a protest against "Man sleeps, luck is awake".

We may choose as a typical example Vaivainen varahin nousi, kova onni kohta kanssa, "The poor man got up early in the morning, hard luck immediately after." In the earliest material there are I I variants equally distributed in eastern and western Finland. The most recent western variant is from I 885 and the most recent one from Eastern Finland is from 1936 . We are confronted with a dying tradition: destruction begins in the west and spreads gradually to the east. Conditions are the same as in old Finnish poems, marriage rites etc.: the eastern periphery keeps a vanishing tradition the longest.

3. In his book Die altgermanische Dichtung Andreas Heusler compared Old Nordic proverbs with more recent ones. He characterized the difference in the following way: "Der Blick auf die Welt (scil. in the old proverbs) ist männlich und kühl, wehrhaft und misstrauisch. Humor ist selten und nicht 
von der gutmütigen Art. Aus einem sehr grossen Bruchteil dieser Sätze vernehmen wir den herrenhaften, fatalistisch beschatteten Kriegersinn, der uns aus der Heldendichtung, auch aus den Bauern- und Fürstenfehden der Sagas bekannt ist. Die jüngere, uns geläufige Gnomenweisheit ruht mehr im friedlichen Kleinleben, sie hat oft einen gedrückten, entsagenden, oft einen gemütlich-schalkhaften Ton."1

Heusler's view of the basic difference between old and new proverbs came to my mind eleven years ago when I made a little experiment with old and recent favourite Finnish proverbs. The material was the twenty proverbs that recur most frequently among the $I I, 000$ variations of proverbs published or recorded before the fire of Turku in September 1827, and twenty others which recur most often in a similarly sized collection of proverbs from the 1930's. Among the differences that emerged from the 20 old and the 20 new favourite proverbs was a noticeable decrease of fatalistic ideas.

The old group included the following proverbs: Tulee mies merentakainen, ei tule turpehen alainen, The man who is beyond the sea returns, but not the one who lies under the turf. Vuosi vanhan vanhentavi, kaksi lapsen kasvattavi, A year makes the old man aged, two years make the child grow up. fumalall on onnen ohjat, Luojalla lykyn avaimet, ei katehen kainalossa, vihansuovan sormenpäissä, God has the bridles of fortune in his hand, the Creator has the keys of luck, they are not in the arm-pit of the envious, nor on the enemy's fingertips. Tikka kirjava metsässä, ihmisen ikä kirjavampi, The woodpecker of the forest is motley, more motley is human life.

In the most common proverbs of the 1930's there are no counterparts to the sentences and maxims about life and death and the nature of human existence quoted above. The proverb that comes closest to the first group runs: "The sniveller becomes a man, but not the one who laughs unnecessarily." The long fatalistic perspective is lacking here, and this is still more obvious in the other recent favourite proverbs.

There are still no accepted methods of measuring and demonstrating trends of development from one generation of proverb users to another. But in my opinion investigations of frequency can give new information

\footnotetext{
${ }^{1}$ A. Heusler, Die altgermanische Dichtung, Darmstadt I957, p. 68.
} 
concerning the changes that are taking place in the minds and the attitudes of people. In Helsinki we have approximately two million Finnish proverbs, $I, 425,000$ in the Sanakirjasäätiö in the old university building and 500,000 in the Folklore Archives. The latter have been copied and arranged according to two title-words in a big card-index which is now almost ready. The large collection of the Sanakirjasäätio is arranged according to parishes: it is easy to find all proverbs that have been recorded in e.g. Nurmijärvi, but the variant forms of certain proverbs are very difficult to find. Nevertheless, through sufficiently numerous and comprehensive sample tests it has been possible to ascertain that humorous sayings ridiculing blind, deaf, crippled or insane people are proportionally decreasing, or that the main stress of folk humour is moving from local to social and professional conditions.

Fatalism, the belief in fate, unfortunately does not belong to the phenomena that are easily defined or statistically measured. No doubt there are fatalistic and anti-fatalistic proverbs. The common European proverb: "Everyone is the architect, or smith, of his own fortune" is known all over the Finnish area: fokainen on oman onnensa seppä. But in four parishes the anti-fatalistic proverb has been turned into its opposite: in Nilsiä, Sumiainen, Jämsä and Lieto it is said: Kukaan ei ole oman onnensa seppä, "Nobody is the smith of his own fortune". How could statistics be made in such cases? A hundred votes against four? As a matter of fact, it is very interesting that the proverb: "Everyone is the smith of his own fortune" does not occur in Finnish tradition until the $1880^{\circ}$ 's; till then this ancient proverbial idea had obviously been repudiated. In the I880's the threshold had become lower, but opposition showed itself here and there through the antithesis "Nobody is the smith of his own fortune". If we had thousands of variants of "the smith of fortune" from various decades and provinces, we might try to measure statistically the strength and the weakening of the opposition in time and space. But we do not have this. We can only collect more individual cases, without preconceived ideas, and see whether they fit into the pattern or not.

Probably there have always been both activists and fatalists in Finlandand no pure activists or fatalists. Even in the oldest collection of Finnish proverbs, from 1702, activistic opposition asserts itself: Nïn luotu kuin tehdään, "Such is fated as is done". In the I8th century H. G. Porthan records two sharply anti-religious proverbs: Teko pellon jumala, "Work is 
the god of the field", Aura on arpoja parahin, "The plough is the best diviner".

In the more recent collections of proverbs it is easily seen that the fatalistic tradition is diminishing and man's own will and enterprise are more and more unanimously emphasized as the most important causes of success. A sense of uncertainty, danger and powerlessness is - or was - close to disappearance. In the textbooks of the primary schools it is God who holds the bridles of fortune, but in the compositions for the matriculation most students believe that man is the architect of his own fortune. The study of proverbs can primarily record the changes that have taken place in people's minds many years ago, but hardly the processes that are going on at present. The question of whether fatalism is undergoing a revival in the big cities of the atomic age has to be answered by other means. 